\title{
EDUCATION THROUGH OFFICIAL PUBLICITY
}

\author{
By William H. Allen,
}

Director Institute for Public Service, New York.

The extra-curricular influence of schools is far wider than their extra-curricular activities.

The influence of every strong teacher upon his pupil when teacher and child are separated is more important than the influence of direct contact with the child. It is the same with the school's official publicity. Its indirect effects are of wider range and deeper import than its direct effect.

School publicity affects for good or ill all other official publicity. If it is lifeless, insincere, boastful, unconvincing, slovenly edited, it is a low-water mark with which every other city department will tend to find level. If, on the other hand, it is alive, informative, direct, frank-educative--other departments will tend to compete in these respects.

A school superintendent told me recently that his report had been so different from the reports of other town officers that it was necessary for other official reporters to notice the difference. $\mathrm{He}$ had used blocked headings in effective black face type, interesting diagrams and photographs, the short paragraph method of listing achievements and recommendations, and the square facing of taxpayer doubt with school fact. Other reporters could not laugh him out of town meeting if they would. They decided to imitate instead.

More than half their time our twenty odd million school children are out of school. Four fifths of our whole population are not attending school any of the time. If out-of-school time is to be used consciously for educational purposes it must be through other means than the school curriculum and extra activities. Because all employers, all parents, all "bosses," all salesmen are in a teaching relation, it becomes of the utmost importance to see that what's in the air-i.e. what is done to affect teaching outside of schoolwill directly supplement teaching in school.

Official publicity is not only the most effective form of publicity 284 
but it is one of the most important factors in publicly organized education. It concerns most men. In fact it concerns all men. It is the only thing which does concern the whole public. The reader of a paper listens to what a distinguished private citizen says without feeling that it is part of his own responsibility. When he reads what a public official says he instinctively feels that he is reading about himself and speaking to himself about his own work. There are at least

\section{Five Kinds of Official Publicity}

1. Formal addresses such as at commencement and inaugural exercises, or reports to annual meetings

2. Incidental or informal addresses at public meetings, banquets, women's clubs, chambers of commerce, etc.

3. Verbal interviews or matter sent to newspapers whether initiating with the newspaper or with the school official; current reports of school activities

4. Exhibits

5. Annual reports

These five forms are found together in many places. Important educational work is done through each. The exhibit method is found also as part of each of the four other methods. For example, President Godfrey of Drexel Institute uses the graphic method in presenting monthly reports to his board of trustees. William McAndrew, associate superintendent of New York City, employs the graphic method even in writing letters to school commissioners. Dr. Leonard Ayers gives chalk talks and chart talks to teachers' associations.

Formal addresses not only offer occasions for testing public interest and capacity for growth, but bring pressure to bear upon part of the public through the rest of the public and upon officials, including teachers, through the general public. President Finley, of the University of the State of New York and commissioner of public education, makes effective use of the formal address.

The incidental or informal address is in many ways more important than the formal address. The after-dinner or specialoccasion speaker finds an audience off its guard and susceptible, particularly if his remarks are to the point, brief, and breezy. School men are using these occasions extensively. Because their work is vital and full of concrete material they are welcome contributors to local and state meetings of women's clubs, merchants' 
associations, bankers, lawyers, etc. In many cities the school superintendent is the toastmaster paramount. Probably no one has done more to educate through official publicity than President Vincent, of the University of Minnesota, or Mrs. Josephine C. Preston, state superintendent of public education in Washington.

Informal, cumulative publicity like the interview, either grudgingly given on the insistence of a live newspaper or consented to by the editor upon the insistence of a live superintendent, is playing a more important rôle each year. Until quite recently the interview was shunned by cautious superintendents chiefly because it was given a bad reputation by the inveterate self-advertiser. School men are realizing, however, that in order to insure community protection against stampedes they must insure continuous education of the public and must make it easier for newspapers to print the truth and essentials than to print non-truths and non-essentials. Hence we find today the weekly or monthly bulletins printed by universities such as that of North Carolina, and by state departments and normal schools such as Wisconsin's. Then there are written "releases" or notices given out by city superintendents, sometimes through composition classes. The short stories are used, sometimes as features, sometimes as editorials, and sometimes as fillers by newspapers. In some cities-for example, Decatur, Illinois and Madison, New Jersey-from one to five items a week, and from one to three columns are given to school news. Superintendent Albert Leonard of New Rochelle, New York, prepares items sometimes attributed to the superintendent, frequently published as newspaper discoveries. These releases from educational headquarters are today directly educating more individuals than does the educational system itself.

The current report to the board of trustees is not given to newspapers as much as it might be, but is being increasingly used. No month goes by without its own interesting events. It is simply a question whether the newspaper shall be offered a digest of worth while facts or be left to stumble and search for school news.

The exhibit and the annual report are two forms of publicity which involve all the technique and principles of the three other forms, and which disclose all their deficiencies, plus several others. Special attention, therefore, is here given to publicity as expressed through the annual report and formal, cumulative exhibit. 


\section{EdUCATION THROUgh ExhiBITS}

Education through exhibits has become a popular form of education-and of diversion! Four kinds are increasingly used by educators-special, current, traveling, report.

Special exhibits bring to mind the kind of thing which was done at the Panama Pacific Exposition in San Francisco and which is being done by book companies and school systems at meetings of state and national education associations. As part of state fairs we have annual exhibits of school work including "high spots" in domestic science, handwriting, corn growing, etc., selected from competitive school tests first in villages and then in counties. During its recent centennial celebration Indiana made its state house at Indianapolis an extensive and live exhibit of contrasts and advances, largely contributed by counties.

The current exhibit is of special interest because it changes and grows from month to month as improvements are brought to light. Many principals keep a running exhibit of the best work of their schools, on class blackboards, in hallways, and in the principal's office. Superintendents are beginning to keep bulletin boards which are current exhibits of the best material from outside the city and from within.

The traveling exhibit is not yet familiar in the school field. Few exhibits have been circulated. That is, they have been exchanged, but even within cities where central exhibits are held, it is not customary as it should be to circulate at least miniature exhibits to all schools-as was done in New York with dental and tuberculosis exhibits. It is as true of exhibits as of any form of merchandise that the exhibit must go to the patron and not wait for him to come to it. There is greater reason for having an "education train" sent at public expense from place to place than for sending a grain car or a health car. What would happen to schools if we sent a "high spot" car or an exhibit of best things in education, including moving pictures, victrolas, cooking and shop work, to every railroad station?

The moving picture has not been adapted as extensively as must soon be done. Films are available without cost to show industrial processes. Routine work of schools must be filmed. Shortly all schools and classes must have what many now have-movable photograph apparatus for moving pictures. 
One by-product of the exhibit method has not yet been worked out systematically enough-i.e. the opportunity to give children and students live problems to work out in arithmetic, percentage, cost and drawing. College men and women still pick dry leaves and measure widths and breadths in order to learn the meaning of averages, norms, and medians! How much more profitable it would be to spend their time measuring empty rooms, finding the unit costs of instruction, diagramming improvements in scholarship, listing alumni achievements and university needs-not-met, the University of Wisconsin's biennial exhibit by students indicates. For the Shakespeare tercentenary elementary and high school pupils throughout the land devised and made costumes, gardens, stages, etc.

\section{The Educational Report}

A large number of reports have been read recently by the Institute for Public Service at the request of school superintendents and presidents of colleges and universities. Among evidences noted that the educational opportunity has not been capitalized by official reporters are these:

1. Unattractive cover

2. Delay in addressing the audience-reports come too late and reporters take too many pages getting started

3. Crowded page or chart

4. Too small type

5. Absence of photographs, or too few

6. Lack of graphic illustration

7. Failure to list advance steps

8. Failure to list needs

9. Failure to make recommendations

10. Failure to state how much the carrying out of recommendations would cost

11. Failure to base recommendations on facts or to relate them to facts

12. Failure to support recommendations by facts and interpret actions

13. Using generalization rather than concrete facts, often when concrete facts are available

14. Too much is placed on charts, in correcting which the Child Federation of Philadelphia has made special progress in exhibits which can be found described in pamphlets issued upon request

15. Chart material, etc., has been elaborated too little orally at exhibits. The best chart work possible can be made much more effective if supplemented by a live interpreter. In reports on the other hand charts are explained too much and need too much explanation. Obviously the purpose of a diagram is to help 
carry the load-it adds to the load if its story needs interpretation-as moving picture concerns quickly learn!

16. Live exhibits have been used too little, such as children in relay races in arithmetic, or giving demonstrations of trade work, or doing regular classroom work

17. Cartoons and humor are too rare-the Russell Sage Foundation has "legitimized" them in its reports on Cleveland schools

18. Too much is told at a time. Reports must be issued in installments as by New York City and the Cleveland school survey

19. Interest is exhausted by too many salutations from subordinates to chief, and by allowing deans or division heads to "ramble, ramble." Requiring brief lists of advance steps, studies made, obstacles and needs will help cure this defect

20. There is too much writing to dead predecessors or distant professional colleagues and too little writing to those who furnish the children or students and pay the bills. That accounts largely for the rareness of self-study, auto-study, analytical comparative review of what education is costing and how its product compares with its opportunity

The best annual reports are the livest, freshest, strongest material available on education. They are a decade or a generation ahead of books. Long before bookmakers crystallize the best experience for the help of isolated administrators many of those isolated men and women have been expressing doubt or demonstrating improvements in their annual reports. The General Education Board's book pictures, 1916, of the Rural School of Tomorrow and The Modern School (which may be procured upon request, 61 Broadway, New York City) read like ancient history to the vanguard of rural and urban educators.

So much does education of the public depend upon official publicity that the report broker must soon come to be as usual as the play broker or the consulting engineer. In addition to attending colleges of education to hear how schools should be administered from those who never administered schools educational reporters will take a summer perhaps by correspondence in the study of their own reports and other official publicity. At any rate it will soon be generally true that educators will recognize two essentials to progressive growth:

1. Official publicity is the educator's greatest opportunity

2. Preparedness for official publicity will more and more require such daily working, daily analyzing, and daily recording as will erect the structure of which official publicity at its best is only the reflection. 